\title{
Evaluation of Laser Effects on the Human Body After Laser Therapy
}

\author{
Ensieh Khalkhal ${ }^{1}$, Mohammadreza Razzaghi ${ }^{2}$, Mohammad Rostami-Nejad ${ }^{3}$, Majid Rezaei-Tavirani ${ }^{4}$, Hazhir \\ Heidari Beigvand ${ }^{4}$, Mostafa Rezaei Tavirani ${ }^{{ }^{*}}$
}

${ }^{1}$ Proteomics Research Center, Faculty of Paramedical Sciences, Shahid Beheshti University of Medical Sciences, Tehran, Iran

${ }^{2}$ Laser Application in Medical Sciences Research Center, Shahid Beheshti University of Medical Sciences, Tehran, Iran ${ }^{3}$ Gastroenterology and Liver Diseases Research Center, Research Institute for Gastroenterology and Liver Diseases, Shahid Beheshti University of Medical Sciences, Tehran, Iran

${ }^{4}$ Firoozabadi Hospital, Faculty of Medicine, Iran University of Medical Sciences, Tehran, Iran

\section{*Correspondence to Mostafa Rezaei-Tavirani, Proteomics Research Center (PRC), Darband St., Qods Sq. Tehran, Iran Tel: +982122714248; Email: tavirany@yahoo.com \\ Published online January 18, 2020}

\begin{abstract}
Lasers have wide applications in the treatment and diagnosis of diseases and various medical fields. Laser therapy like the other methods has advantages and disadvantages. Some risks such as bleeding, pain, and infection are created after laser therapy. Explanation and evaluation of laser effects on cell function, tissue, and the body are the aims of this study. We reviewed papers available from 1986 to 2019 about the effects of lasers on cells and tissue. An online search of PubMed, Science Direct and Google scholar using such keywords as "laser", "cell", "tissue", "body" and "side effects" was performed. The laser photons are absorbed by chromophores, resulting in the target heating and localized damage. Laser irradiation alters cellular metabolism and cellular functions. These alterations may be accompanied by undesired side effects which can be monitored via metabolites level change in the body. Based on this finding, laser therapy may be associated with several side effects and complications; therefore, before treatment, the determination of laser types and their properties is necessary to avoid creating side effects. The advantages and disadvantages of the treatment type should be considered in order to choose the best treatment with the least side effects. The patients' awareness of possible side effects before treatment and also an effective follow-up and management of patients after action are two important points in laser therapy. Training curriculum definition should be determined for laser applicant qualifications in different medical fields.
\end{abstract}

Keywords: laser therapy; Cell; Tissue; Body. therapy is a form of medicine that applies laser radiation to the surface of the body. While lasers are used to cut or remove tissue, relieve pain, reduce inflammation and edema, promote wounds, prevent tissue damage, and heal deeper tissues and nerves in medicine, they stimulate and enhance cell and tissue function. The effects of lasers are confined to the special set of wavelengths. Several studies indicate that laser therapy may be effective in relieving pain for nervous system diseases ${ }^{4,5}$ such as trigeminal neuralgia, ${ }^{6}$ rheumatoid arthritis, ${ }^{7}$ chronic neck pain, ${ }^{8}$ and osteoarthritis. ${ }^{9}$ Photons are absorbed by the electron absorption bands of the receptors called chromophores and cause the effects. The main tissue chromophores including hemoglobin and melanin have high absorption bands during shorter waves. Also, water strongly absorbs infrared photons at wavelengths above $1100 \mathrm{~nm}$. Therefore, using low-level lasers in medicine is known as a suitable tool. Low-Level Lasers such as ruby, 
Argone, HeNe, and Krypton are types of lasers that affect biological systems through non-thermal means. ${ }^{10}$ In order to influence the visible light exposure to a living biological system, it can absorb photons by using electron capture bands belonging to some molecular photo-receptors. When the tissue chromophores, often hemoglobin, water or melanin, are affected by laser energy, the photon is absorbed, so it causes the target material to heat up and inflicts localized damage. In addition, laser energy is absorbed more rapidly and intensively through the skin and then causes localized damage. ${ }^{11}$ Furthermore, the person who directs the laser must be fully trained and skilled because lasers of an unspecified purpose can burn or destroy healthy tissue. Treatment complications of laser therapy may occur following the application of different types of laser devices and must be anticipated. In this article, we explain and evaluate several effects of lasers on cell functions, tissue, and the body.

\section{Methods}

Papers which explain the effects of lasers on cells, tissue and organisms and also laser therapy complication in the online journals that were published from 1986 to 2019 were searched. An online search of PubMed, Science Direct and Google scholar using such keywords as "laser", "cell", "tissue", "body" and "side effects" was performed. All documents in the English language were considered. The titles were screened and the suitable abstracts were studied. Finally, the appropriate articles were selected and the full text of these documents was extracted.

Introducing Laser Devices and Tissue Chromophores Various types of laser devices are used in medicine. Table 1 demonstrates a list of laser types, their applications, and their properties., ${ }^{32-14}$ The fields in which relevant lasers are applied are also shown in Table 1. Tissue chromophores that absorb laser photons and the related absorbed wavelengths are tabulated in Table $2 .{ }^{15,16}$ Nucleic acid, protein, hemoglobin, melanin, water, lipid, elavins, and cytochrome oxidase are highlighted as chromophores.

\section{Epidermal Side Effects of Laser Therapy}

Laser therapy has been used for forty years to reduce pain, swelling, and inflammation, prevent tissue damage, heal wounds, and treat deeper tissues and nerves. In these fields, the laser stimulates or inhibits cell and tissue function which leads to clinical effects finally. ${ }^{17-20}$

Before laser therapy, patients' history including abnormal scarring, allergy, excessive sun exposure, herpes virus infection, any vascular and immunological disorders, tissue reinforced with silicone, smoking, and former cosmetic surgery must be considered. Because many drugs including amiodarone, minocycline, warfarin, isotretinoin, aspirin, niacin, vitamin $\mathrm{E}$ cause delayed healing, bleeding, scarring, increased bruising, hyperpigmentation, and localized chrysiasis after laser therapy, the medications that the patients have taken must be considered. ${ }^{21-23}$

The open wounds that are created after laser resurfacing and laser tattoo removal require daily care to optimize healing. Otherwise, infection, persistent erythema, and scarring are created. There are a variety of complications after reconstructive surgery and facial rejuvenation using $\mathrm{CO} 2$ and Er: YAG lasers. These include bacterial and viral infections, pain, persistent erythema, delayed healing, scarring, hypopigmentation, hyperpigmentation, acne,

Table 1. The List of Various Lasers Which Are Used in the Treatment of Different Types of Diseases and the Application Cases and Their Properties

\begin{tabular}{|c|c|c|c|}
\hline Laser Type & Wavelength (nm) & Chromophore & Application \\
\hline Ruby & 694 & Pigment, hemoglobin & Dermatology \\
\hline Nd:YAG & 1064 & Pigment, proteins, hemoglobin & Wide application \\
\hline Ho:YAG & 2130 & Water & Surgery, root canal lithotripsy \\
\hline Er:YAG & 2940 & Water & Surgery, dental drill \\
\hline KTP & 532 & Pigment, hemoglobin & Dermatology \\
\hline Alexandrite & $720-800$ & Pigment & Bone cutting \\
\hline $\mathrm{HeNe}$ & 633 & Pigment, hemoglobin & Photodynamic therapy \\
\hline Argone & $350-514$ & Pigment, hemoglobin & Surgery, photodynamic therapy, dermatology \\
\hline Diod lasers & 630-98 0nm & Pigment, water, proteins & Photodynamic therapy surgery \\
\hline $\mathrm{Co} 2$ & 10600 & Water & Surgery \\
\hline ArF Excimer & 193 & Proteins & Corneal surgery \\
\hline XeCl Exicimer & 308 & Proteins, lipids & Dermatology \\
\hline Nitrogen & 337 & Pigment & Dermatology \\
\hline Copper Vapor & 578 & Pigment & Dermatology \\
\hline Gold Vapor & 628 & Pigment & Photodynamic therapy \\
\hline Argon-pumped dye & $630-690$ & Pigment & Photodynamic therapy \\
\hline KTP pumped dye & $630-635$ & Pigment & Photodynamic therapy \\
\hline Flash lamp pumped dye & $580-600$ & Pigment & Dermatology \\
\hline
\end{tabular}


Table 2. Various Types of Tissue Chromophores and Their Main Absorption Wavelengths

\begin{tabular}{lc}
\hline Chromophores & Absorption Wavelengths (nm) \\
\hline Nucleic acid & $260-280$ \\
Protein & $280-300$ \\
Hemoglobin & $400,542,554,576$ \\
Melanin & $400-800$ \\
Water & $1400-10000$ \\
Flavins & $420-500$ \\
Cytochrome oxidase & $620-900$ \\
\hline
\end{tabular}

milia, ectropion, pruritus, contact dermatitis, vascular proliferation, and eruptive keratoacanthomas. ${ }^{24-28}$

Now many new pulsed dye laser generations are available with variable pulse duration, longer wavelengths, faster repetition rates, larger spot sizes, and epidermal cooling devices. Although these upgraded devices improve clinical results, some complications and side effects have not been eliminated completely. For example, several complications of pulsed dye laser therapy such as purpura, blisters, pain, crusting, hypopigmentation, hyperpigmentation, dermatitis, and atrophic scarring have remained. ${ }^{29,30}$ However, researchers have identified that laser therapy is associated with a relatively low complication rate. The complications and side effects that are observed after laser treatment are temporary and are not dramatically severe or do not lead to long-term effects. ${ }^{31}$

\section{Effects of Laser on Cell Function}

In cells, mitochondria are the first site to show the early effects of laser with photon absorption. After photon absorption by the cytochrome $c$ oxidase enzyme, the chromophore for the red-NIR range, an electron-excited state, and an intensified electron transfer reaction are up- regulated. This process leads to the increment of ATP production, the modulation of reactive oxygen species, and the induction of expression of TNF transcription factors. ${ }^{32}$ Changes in cellular redox status regulate many transcription factors such as NF- $\kappa$ B, Ref-1, p53, ATF/ CREB, and HIF-1 $\alpha$. This then induces transcriptional changes and the activation of several intracellular signaling pathways such as protein synthesis, nucleic acid synthesis, cell cycle progression, and enzyme activation. Additionally, it stimulates the differentiation of some cell types ${ }^{33}$ and leads to increased cell proliferation and cell migration, growth factors and inflammatory mediators, and the modulation of cytokines (Figure 1). ${ }^{34}$ All mentioned alterations are accompanied by possible dysregulation in the molecular mechanism of cell function because cell proliferation and cell cycle progression are important processes on which cell function depends. ${ }^{35}$ Also, lasers alter cellular metabolism and transcription factors which are responsible for gene expression. ${ }^{36}$

\section{Metabolomic Effect of Laser}

Intravascular laser blood irradiation is used in the treatment of various diseases. Laser irradiation therapy influences the whole of organisms, cells, and tissues and it may alter the metabolome profile. It induces ATP synthesis and energy formation in cells, reduces the status of glucose, cholesterol, low-density lipoproteins, and very low-density lipoproteins, stabilizes the hormonal and immune system, and increases arginine and nitric oxide production. Arginine causes the release of some hormones such as glucagon, insulin, growth hormone, adrenalin, prolactin, and catecholamines. ${ }^{37-39}$ In diabetic patients, after laser blood irradiation, levels of main metabolites such as glucose, glucose-6-phosphate, dehydroascorbic acid, R-3-hydroxybutyric acid, L-histidine, and L-alanine decrease and $\mathrm{L}$-arginine increase in plasma. ${ }^{40}$

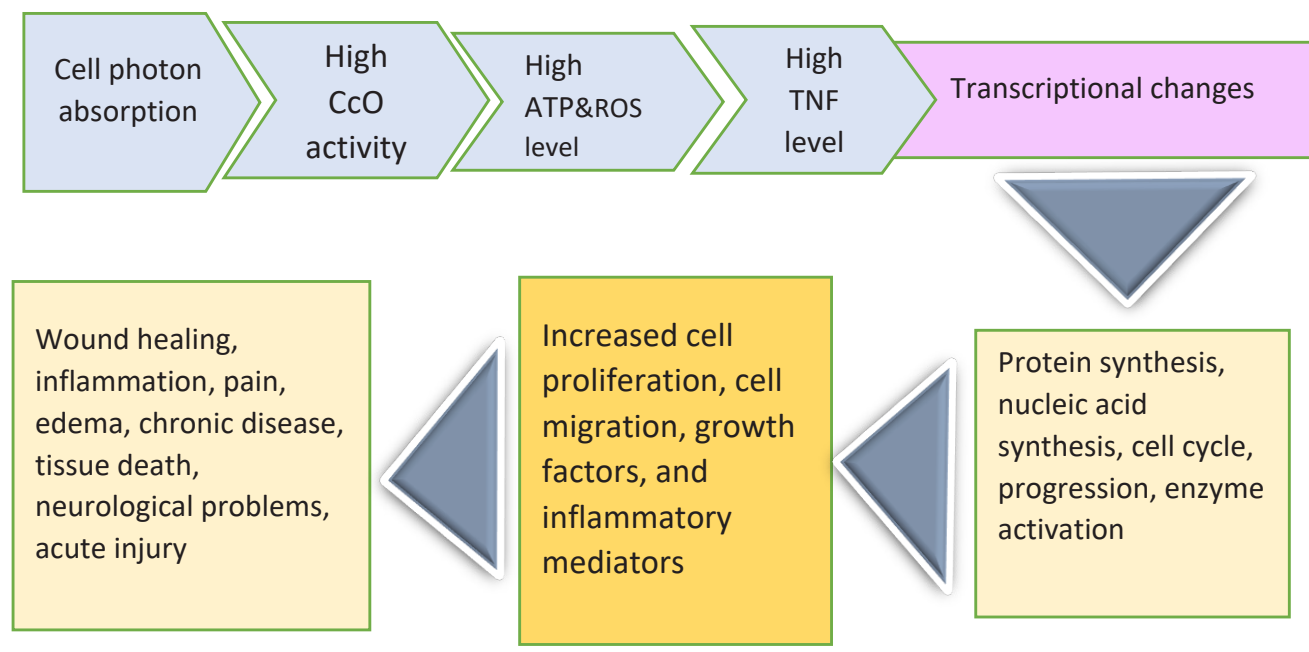

Figure 1. A Schematic View of Laser Effects on Cellular Function. Processes start with photon absorption and end to the related biological effects. 


\section{Hypertrichosis After Laser Therapy}

In 1996 after the approval of FDA, because of the relative safety and efficacy of lasers and highly pulsating lasers (HPLs) treatments, HPLs were commonly used to terminate unwanted hair growth by using laser wavelengths in the red and 600-1100 $\mathrm{nm}$ range and pulsing light energy to melanin in hair shafts. Upon absorption, the light converts to thermal energy and destroys the hair follicle precursor cells while destroying the surrounding tissue. ${ }^{41,42}$ After a few months, Hypertrichosis, a rare and significant side effect, occurs in areas treated with laser devices with low fluencies and all laser types ${ }^{43}$ such as Nd:YAG, diode lasers, and alexandrite lasers. ${ }^{44-48}$ Hypertrichosis is the result of suboptimal rays that are too low to stimulate thermolysis and high enough to induce follicular growth and convert follicles from telogen (resting phase) to anagen (active phase) or transform vascular follicles into terminal follicles. It mostly occurs in the patients' face and neck with darker skin and coarse hair with hormonal imbalances. ${ }^{10,13}$ Its pathogenesis includes the regulation of prostaglandin $\mathrm{E}_{2}$ (inflammatory mediator) production by ultraviolet radiation and stimulation. Reversible hypertrichosis and hair growth occur when it is applied topically. ${ }^{49,50}$

\section{Diabetic Retinopathy and Laser Therapy}

Diabetic retinopathy laser therapy is an effective treatment to prevent vision loss in diabetic patients. Laser therapy is an effective method for preventing vision loss and maintaining long-term vision, but it is inherently destructive and is associated with side-effects, especially with regards to dark adaptation, peripheral visual function, and night vision. ${ }^{14,51}$

Laser photon is absorbed by pigment cells in the retina, thereby increasing the temperature in the cell and heating it and thus destroying the outer retina cells including the outer receptor photon and the retinal pigment epithelium. Therefore, the laser burns and leads retinal to thinning and results in an increased retinal ability to extract oxygen from the choroid. Thinning of the retina improves relative oxygenation in the retinal tissue, but it is ischemic destruction and retina also decreases the release of angiogenic growth factors such as VEGF. This process leads to regression or disappearance of retinal vascular vessels..$^{52-55}$

Pain, development of macular edema, losing visual field, reduction in night vision, color vision loss, retinal scarring, and reduction in contrast sensitivity are seen in several diabetic patients after retinopathy laser therapy. ${ }^{56-58}$ However, most patients are able to tolerate pain, but shortening the duration of the laser pulse, specifically avoiding prolonged posterior nerves in three to nine hours' position and failing treatment in a few sessions can reduce pain and improve patients' condition. Using longer laser wavelengths is more uncomfortable and limits the ability to tolerate pain in some patients. ${ }^{59-61}$
Although macular edema is resolved within weeks to months after laser therapy in some patients, it can lead to their loss of visual acuity. To reduce macular edema after laser therapy, the number of laser spots delivered per session must decrease. ${ }^{62-64}$

The negative effect of lasers on peripheral visual fields has been studied by evaluating the visual correctness of different laser techniques. Scores for the visual field in diabetic patients after laser therapy on the four-year visit are worse and the visual field reduces. Moreover, diminished color vision after laser therapy is reported. ${ }^{65,66}$ Decreased night vision and contrast sensitivity have also been reported following laser therapy in several studies. ${ }^{67}$ Choroidal detachment or effusions, commonly and potentially adverse effects of laser therapy, lead to the anterior angle shallowing, elevated intraocular pressure or angle closure glaucoma and are resolved with any treatment and rarely cause visual sequelae. ${ }^{68}$ Vascular congestion of the choroid almost happens after xenon or argon laser therapy and causes the eyelashes to rotate to the shallow anterior chamber and transiently increases intraocular pressure. This can lead to transient accommodation and transient myopia or transient increased intraocular pressure. ${ }^{69}$

Laser therapy can result in misdirected or excessively intense burns, bleeding from the choriocapillaris, damage to macular and other ocular structures, and breaks in Bruch's membrane. The use of excessive energy in laser therapy breaks Burch's membrane and then fibroblast growth factor synthesis and the retinal pigment epithelium active to synthesize vascular endothelial growth factor that leads to the development of choroidal neovascularization..$^{70-72}$

In several patients after the laser procedure, many side effects including choroidal detachment, hollowing of the anterior chamber, exudative retinal detachment, and increased intraocular pressure are reported. ${ }^{73,74}$

After laser therapy, we need to follow up patients and checkup some factors such as change and appearance in vessels, vitreous hemorrhage frequency and extent, vitreous detachment status, scars extent, and fibrous proliferations extent from the last retinopathy laser therapy on. ${ }^{75}$

\section{Conclusion}

Laser therapy requires highly trained and skilled people who have to carry out the laser procedure and give precautions after surgery to the patient, and caring after the laser operation is very important to get the desired result. Some after-effects of treatment, such as scarring and hypopigmentation may appear several months after laser application. Laser therapy is not a method without side effects and most of the times it is accompanied by failures. The probability of adverse side effects should be meticulously compared to beneficial results to make a reasonable clinical decision from one patient to the 
other. Patient satisfaction is an important point and many side effects cannot be avoided; therefore, all possible risks and potential complications after laser therapy should be explained to patients. Patients should be aware of long-term risks before laser therapy. If an undesirable complication is managed immediately, the prevention of permanent damage may be possible.

\section{Ethical Considerations}

Not applicable.

\section{Conflict of Interests}

The authors declare no conflict of interest.

\section{References}

1. Khalkhal E, Rezaei-Tavirani M, Zali MR, Akbari Z. The Evaluation of Laser Application in Surgery: A Review Article. J Lasers Med Sci. 2019;10(suppl1):S104-S111. doi: 10.22037/jlms.v10i4.27719.

2. Rezaei-Tavirani M, Rezaei Tavirani M, Zamanian Azodi M, Moravvej Farshi H, Razzaghi M. Evaluation of skin response after erbium: yttrium-aluminum-garnet laser irradiation: a network analysis approach. J lasers Med Sci. 2019;10(3):194-99. doi: 10.15171/jlms.2019.31.

3. Maiman TH. Stimulated optical radiation in ruby. Nature. 1960;187:493-4. doi:10.1038/187493a0.

4. Iijima K, Shimoyama N, Shimoyama M, Yamamoto T, Shimizu T, Mizuguchi. Effect of repeated irradiation of low-power $\mathrm{He}-\mathrm{Ne}$ laser in pain relief from postherpetic neuralgia. Clin J Pain. 1989;5(3):271-4. doi: 10.1097/00002508-198909000-00013.

5. Shaver SL, Robinson NG, Wright BD, Kratz GE, Johnston MS. A multimodal approach to management of suspected neuropathic pain in a prairie falcon (Falco mexicanus). $J$ Avian Med Surg. 2009;23(3):209-13. doi: 10.1647/2008038.1 .

6. Walker J, Akhanjee L, Cooney M, Goldstein J, Tamzyoshi S, Segal-Gidan F. Laser therapy for pain of trigeminal neuralgia. Clin J Pain. 1987;3(4):183-8.

7. Brosseau L, Welch V, Wells GA, de Bie R, Gam A, Harman $\mathrm{K}$, et al. Low level laser therapy (Classes I, II and III) for treating rheumatoid arthritis. Cochrane Database Syst Rev. 2005(4):CD002049. doi: 10.1002/14651858.CD002049. pub2.

8. Irnich D, Behrens N, Gleditsch JM, Stör W, Schreiber MA, Schöps P, et al. Immediate effects of dry needling and acupuncture at distant points in chronic neck pain: results of a randomized, double-blind, sham-controlled crossover trial. Pain. 2002;99(1-2):83-9. doi: 10.1016/ s0304-3959(02)00062-3.

9. Jamtvedt G, Dahm KT, Christie A, Moe RH, Haavardsholm E, Holm I, et al. Physical therapy interventions for patients with osteoarthritis of the knee: an overview of systematic reviews. Phys Ther. 2008;88(1):123-36. doi: 10.2522/ ptj.20070043.

10. Lin F, Josephs SF, Alexandrescu DT, Ramos F, Bogin V, Gammill V, et al. Lasers, stem cells, and COPD. J Transl Med. 2010;8(1):16. doi: 10.1186/1479-5876-8-16.

11. Vreman HJ, Wong RJ, Stevenson DK, editors. Phototherapy: current methods and future directions. Seminars in perinatology. Semin Perinatol. 2004;28(5):326-33. doi: 10.1053/j.semperi.2004.09.003.

12. Natto ZS, Aladmawy M, Levi PA Jr, Wang HL. Comparison of the efficacy of different types of lasers for the treatment of peri-implantitis: a systematic review. Int J Oral Maxillofac Implants. 2015;30(2):338-45. doi: 10.11607/jomi.3846.

13. Agrawal R, Wang C. Laser Beam Machining. In: Bhushan B, editor. Encyclopedia of Nanotechnology. $2^{\text {nd }}$ ed. Netherlands: Springer;2016. P.1739-1753. doi:10.1007/97894-007-6178-0_101020-1.

14. Deschler EK, Sun JK, Silva PS. Side-effects and complications of laser treatment in diabetic retinal disease. Semin Ophthalmol. 2014;29(5-6):290-300. doi: 10.3109/08820538.2014.959198.

15. Carroll L, Humphreys TR. LASER-tissue interactions. Clinics in dermatology. 2006 Jan 1;24(1):2-7.

16. Rawlins J, Din JN, Talwar S, O'Kane P. Coronary intervention with the excimer laser: review of the technology and outcome data. Interv Cardiol. 2016;11(1):27-32. doi: 10.15420/icr.2016:2:2.

17. Karu T. The science of low-power laser therapy. Netherlands: Gordon \& Breach Science Publishers; 1998.

18. Mansouri V, Rezaei-Tavirani M, Zadeh-Esmaeel MM, Rezaei-Tavirani S, Razzaghi M, Okhovatian F, et al. Analysis of Laser Therapy Effects on Squamous Cell Carcinoma Patients: A System Biology Study. J Lasers Med Sci. 2019;10(suppl 1):S1-S6. doi: 10.15171/jlms.2019.S1.

19. Shahrokh S, Razzaghi Z, Mansouri V, Ahmadi N. The impact of Proteomic investigations on the development and improvement of skin laser therapy: A Review Article. J Lasers Med Sci. 2019;10(suppl 1):S90-5. doi: 10.15171/ jlms.2019.S16.

20. Momenzadeh S, Koosha A, Kazempoor Monfared M, Bairami J, Zali A, Ommi D, et al. The Effect of Percutaneous Laser Disc Decompression on Reducing Pain and Disability in Patients With Lumbar Disc Herniation. J Lasers Med Sci. 2019;10(1):29-32. doi: 10.15171/jlms.2019.04.

21. Hædersdal M, Poulsen T, Wulf HC. Laser induced wounds and scarring modified by antiinflammatory drugs: a murine model. Lasers Surg Med. 1993;13(1):55-61. doi: 10.1002/lsm.1900130111.

22. Trotter MJ, Tron VA, Hollingdale J, Rivers JK. Localized chrysiasis induced by laser therapy. Arch Dermatol. 1995;131(12):1411-4. doi: 10.1001/ archderm.1995.01690240073012.

23. Walia S, Alster TS. Cutaneous CO2 laser resurfacing infection rate with and without prophylactic antibiotics. Dermatol Surg. 1999;25(11):857-61. doi: 10.1046/j.15244725.1999.99114.x.

24. Kelly KM, Nelson JS, Lask GP, Geronemus RG, Bernstein LJ. Cryogen spray cooling in combination with nonablative laser treatment of facial rhytides. Arch Dermatol. 1999;135(6):691-4. doi: 10.1001/archderm.135.6.691.

25. Alster TS, Williams CM. Treatment of nevus of Ota by the Qswitched alexandrite laser. Dermatol Surg. 1995;21(7):5926. doi: 10.1111/j.1524-4725.1995.tb00512.x.

26. Grossman MC, Anderson RR, Farinelli W, Flotte TJ, Grevelink JM. Treatment of cafe au lait macules with lasers: a clinicopathologic correlation. Arch Dermatol. 1995;131(12):1416-20. doi: 10.1001/ 
archderm.1995.01690240080013.

27. Manaloto RM, Alster T. Erbium: YAG laser resurfacing for refractory melasma. Dermatol Surg. 1999;25(2):121-3. doi: 10.1046/j.1524-4725.1999.08103.x.

28. McDaniel DH, Lord J, Ash K, Newman J, Zukowski M. Laser hair removal: a review and report on the use of the long-pulsed alexandrite laser for hair reduction of the upper lip, leg, back, and bikini region. Dermatol Surg. 1999;25(6):425-30. doi: 10.1046/j.1524-4725.1999.08118.x.

29. Stratigos AJ, Dover JS, Arndt KA. Laser treatment of pigmented lesions--2000: how far have we gone? Arch Dermatol. 2000;136(7):915-21. doi: 10.1001/ archderm.136.7.915

30. McBurney EI. Side effects and complications of laser therapy. Dermatol Clin. 2002;20(1):165-76. doi: 10.1016/ s0733-8635(03)00054-8.

31. Graber EM, Tanzi EL, Alster TS. Side effects and complications of fractional laser photothermolysis: experience with 961 treatments. Dermatol Surg. 2008;34(3):301-7. doi: 10.1111/j.1524-4725.2007.34062.x.

32. Turrens JF. Mitochondrial formation of reactive oxygen species. J Physiol. 2003;552(Pt2):335-44. doi: 10.1113/ jphysiol.2003.049478.

33. Alaluf S, Muir-Howie H, Hu HL, Evans A, Green MR. Atmospheric oxygen accelerates the induction of a postmitotic phenotype in human dermal fibroblasts: the key protective role of glutathione. Differentiation. 2000;66(23):147-55. doi: 10.1046/j.1432-0436.2000.660209.x.

34. Pastore D, Greco M, Petragallo V, Passarella S. international $\mathrm{mb}$. Increase in <-- $\mathrm{H}+/ \mathrm{e}$ - ratio of the cytochrome c oxidase reaction in mitochondria irradiated with helium-neon laser. Biochem Mol Biol Int. 1994;34(4):817-26.

35. Kamal KY, Herranz R, van Loon JJWA, Medina FJ. Cell cycle acceleration and changes in essential nuclear functions induced by simulated microgravity in a synchronized Arabidopsis cell culture. Plant Cell Environ. 2019;42(2):480-94. doi: 10.1111/pce.13422.

36. Orten SS, Waner M, Flock S, Roberson PK, Kincannon J. Port-wine stains: An assessment of 5 years of treatment. Arch Otolaryngol Head Neck Surg. 1996;122(11):1174-9. doi: 10.1001/archotol.1996.01890230022005.

37. Godden PM, Weekes TE. Insulin, prolactin and thyroxine responses to feeding, and to arginine and insulin injections during growth in lambs. J Agric Sci. 1981;96(2):353-62. doi: 10.1017/S0021859600066144

38. Makela AM. Theoretical backgrounds for light application in diabetes. Laser Florence, 2004.

39. Anu M. Makela M.D. Role of L-arginine in the biological effects of blue light. Processing. SPIE 5968, Laser Florence 2004: A Window on the Laser Medicine World, (25 October 2005). doi:10.1117/12.660038

40. Kazemi Khoo N, Iravani A, Arjmand M, Vahabi F, Lajevardi M, Akrami SM, et al. A metabolomic study on the effect of intravascular laser blood irradiation on type 2 diabetic patients. Lasers Med Sci. 2013;28(6):1527-32. doi: 10.1007/ s10103-012-1247-4.

41. Tanzi EL, Lupton JR, Alster TS. Lasers in dermatology: four decades of progress. J Am Acad Dermatol. 2003;49(1):1-34. doi: $10.1067 / \mathrm{mjd} .2003 .582$.

42. Rangwala S, Rashid RM. Alopecia: a review of laser and light therapies. Dermatol Online J. 2012;18(2):3.
43. Desai S, Mahmoud BH, Bhatia AC, Hamzavi IH. Paradoxical hypertrichosis after laser therapy: a review. Dermatol Surg. 2010;36(3):291-8. doi: 10.1111/j.15244725.2009.01433.x

44. Bouzari N, Tabatabai H, Abbasi Z, Firooz A, Dowlati Y. Laser hair removal: comparison of long-pulsed $\mathrm{Nd}$ : YAG, long-pulsed alexandrite, and long-pulsed diode lasers. Dermatol Surg. 2004;30(4 Pt 1):498-502. doi: 10.1111/j.1524-4725.2004.30163.x.

45. Bernstein EF. Hair growth induced by diode laser treatment. Dermatol Surg. 2005;31(5):584-6. doi: 10.1111/ j.1524-4725.2005.31168.

46. Willey A, Torrontegui J, Azpiazu J, Landa N. Hair stimulation following laser and intense pulsed light photoepilation: Review of 543 cases and ways to manage it. Lasers Surg Med. 2007;39(4):297-301. doi: 10.1002/lsm.20485.

47. Kontoes P, Vlachos S, Konstantinos M, Anastasia L, Myrto S. Hair induction after laser-assisted hair removal and its treatment. J Am Acad Dermatol. 2006;54(1):64-7. doi: 10.1016/j.jaad.2005.09.034.

48. Radmanesh M. Paradoxical hypertrichosis and terminal hair change after intense pulsed light hair removal therapy. J Dermatolog Treat. 2009;20(1):52-4. doi: 10.1080/09546630802178224.

49. Orengo IF, Gerguis J, Phillips R, Guevara A, Lewis AT, Black HS. Celecoxib, a cyclooxygenase 2 inhibitor as a potential chemopreventive to UV-induced skin cancer: a study in the hairless mouse model. Arch Dermatol. 2002;138(6):751-5. doi: 10.1001/archderm.138.6.751.

50. Cohen JL. Commentary: from serendipity to pilot study and then pivotal trial: bimatoprost topical for eyelash growth. Dermatol Surg. 2010;36(5):650-1. doi: 10.1111/j.15244725.2010.01532.x.

51. Chew EY, Ferris FL 3rd, Csaky KG, Murphy RP, Agrón E, Thompson DJ, et al. The long-term effects of laser photocoagulation treatment in patients with diabetic retinopathy: the early treatment diabetic retinopathy follow-up study. Ophthalmology. 2003;110(9):1683-9. doi: 10.1016/S0161-6420(03)00579-7.

52. Budzynski E, Smith JH, Bryar P, Birol G, Linsenmeier RA. Effects of photocoagulation on intraretinal PO2 in cat. Invest Ophthalmol Vis Sci. 2008;49(1):380-9. doi: 10.1167/ iovs.07-0065.

53. Manaviat MR, Rashidi M, Afkhami-Ardekani M, Mohiti-Ardekani J, Bandala-Sanchez M. Effect of pan retinal photocoagulation on the serum levels of vascular endothelial growth factor in diabetic patients. Int Ophthalmol. 2011;31(4):271-5. doi: 10.1007/s10792-0119448-6.

54. Itaya M, Sakurai E, Nozaki M, Yamada K, Yamasaki S, Asai K, et al. Upregulation of VEGF in murine retina via monocyte recruitment after retinal scatter laser photocoagulation. Invest Ophthalmol Vis Sci. 2007;48(12):5677-83. doi: 10.1167/iovs.07-0156.

55. Mohamed TA, Mohamed Sel-D. Effect of pan-retinal laser photocoagulation on plasma VEGF, endothelin-1 and nitric oxide in PDR. Int J Ophthalmol. 2010;3(1):19-22. doi: 10.3980/j.issn.2222-3959.2010.01.05.

56. Muqit MM, Marcellino GR, Gray JC, McLauchlan R, Henson DB, Young LB, et al. Pain responses of Pascal $20 \mathrm{~ms}$ multi-spot and $100 \mathrm{~ms}$ single-spot panretinal 
photocoagulation: Manchester Pascal Study, MAPASS report 2. Br J Ophthalmol. 2010;94(11):1493-8. doi: 10.1136/bjo.2009.176677.

57. Blumenkranz MS, Yellachich D, Andersen DE, Wiltberger MW, Mordaunt D, Marcellino GR, et al. Semiautomated patterned scanning laser for retinal photocoagulation. Retina. 2006;26(3):370-6. doi: 10.1097/00006982200603000-00024.

58. Chhablani J, Mathai A, Rani P, Gupta V, Arevalo JF, Kozak I. Comparison of conventional pattern and novel navigated panretinal photocoagulation in proliferative diabetic retinopathy. Invest Ophthalmol Vis Sci. 2014;55(6):3432-8. doi: 10.1167/iovs.14-13936.

59. The Krypton Argon Regression Neovascularization Study Research Group. Randomized comparison of krypton versus argon scatter photocoagulation for diabetic disc neovascularization: the krypton argon regression neovascularization study. Ophthalmology. 1993; 100(11):1655-64. doi: 10.1016/S0161-6420(93)31421-1

60. Luttrull JK, Dorin G. Subthreshold diode micropulse laser photocoagulation (SDM) as invisible retinal phototherapy for diabetic macular edema: a review. Curr Diabetes Rev. 2012;8(4):274-84. doi: 10.2174/157339912800840523.

61. Sheth S, Lanzetta P, Veritti D, Zucchiatti I, Savorgnani C, Bandello F. Experience with the Pascal ${ }^{\circledR}$ photocoagulator: An analysis of over 1200 laser procedures with regard to parameter refinement. Indian J Ophthalmol. 2011;59(2):8791. doi: 10.4103/0301-4738.77007.

62. Shimura M, Yasuda K, Nakazawa T, Kano T, Ohta S, Tamai M. Quantifying alterations of macular thickness before and after panretinal photocoagulation in patients with severe diabetic retinopathy and good vision. Ophthalmology. 2003;110(12):2386-94. doi: 10.1016/j.ophtha.2003.05.008.

63. Brucker AJ, Qin H, Antoszyk AN, Beck RW, Bressler NM, Browning DJ, et al. Observational study of the development of diabetic macular edema following panretinal (scatter) photocoagulation given in 1 or 4 sittings. Arch Ophthalmol. 2009;127(2):132-40. doi: 10.1001/ archophthalmol.2008.565.

64. Googe J, Brucker AJ, Bressler NM, Qin H, Aiello LP, Antoszyk A, et al. Randomized trial evaluating shortterm effects of intravitreal ranibizumab or triamcinolone acetonide on macular edema following focal/grid laser for diabetic macular edema in eyes also receiving panretinal photocoagulation. Retina. 2011;31(6):1009-27. doi: 10.1097/IAE.0b013e318217d739.

65. Henricsson M, Heijl A. The effect of panretinal laser photocoagulation on visual acuity, visual fields and on subjective visual impairment in preproliferative and early proliferative diabetic retinopathy. Acta Ophthalmol (Copenh).1994;72(5):570-5. doi: 10.1111/j.1755-3768.1994. tb07181.x.

66. Fong DS, Girach A, Boney A. Visual side effects of successful scatter laser photocoagulation surgery for proliferative diabetic retinopathy: a literature review. Retina. 2007;27(7):816-24. doi: 10.1097/IAE.0b013e318042d32c.

67. Lövestam-Adrian M, Svendenius N, Agardh E. Contrast sensitivity and visual recovery time in diabetic patients treated with panretinal photocoagulation. Acta Ophthalmol Scand. 2000;78(6):672-6. doi: 10.1034/j.16000420.2000.078006672.x

68. Yuki T, Kimura Y, Nanbu S, Kishi S, Shimizu K. Ciliary body and choroidal detachment after laser photocoagulation for diabetic retinopathy: a high-frequency ultrasound study. Ophthalmology. 1997;104(8):1259-64. doi: 10.1016/s01616420(97)30149-3.

69. Zamir E, Anteby I, Merin S. Choroidal effusion causing transient myopia after panretinal photocoagulation. Arch Ophthalmol. 1996;114(10):1284-5. doi: 10.1001/ archopht.1996.01100140484028.

70. Chappelow AV, Tan K, Waheed NK, Kaiser PK. Panretinal photocoagulation for proliferative diabetic retinopathy: pattern scan laser versus argon laser. Am J Ophthalmol. 2012;153(1):137-42.e2. doi: 10.1016/j.ajo.2011.05.035.

71. Salman AG. Pascal laser versus conventional laser for treatment of diabetic retinopathy. Saudi J Ophthalmol. 2011;25(2):175-9. doi: 10.1016/j.sjopt.2011.01.006.

72. Muraly P, Limbad P, Srinivasan K, Ramasamy K. Single session of Pascal versus multiple sessions of conventional laser for panretinal photocoagulation in proliferative diabetic retinopathy: a comparitive study. Retina. 2011;31(7):1359-65. doi: 10.1097/IAE.0b013e318203c140.

73. Liang JC, Huamonte FU. Reduction of immediate complications after panretinal photocoagulation. Retina. 1984;4(3):166-70. doi: 10.1097/00006982-19840043000007.

74. Sanghvi C, McLauchlan R, Delgado C, Young L, Charles SJ, Marcellino G, et al. Initial experience with the Pascal photocoagulator: a pilot study of 75 procedures. Br J Ophthalmol. 2008;92(8):1061-4. doi: 10.1136/ bjo.2008.139568.

75. ETDRS Research Group J. Techniques for scatter and local photocoagulation treatment of diabetic retinopathy: Early Treatment Diabetic Retinopathy Study Report no. 3. Int Ophthalmol Clin. 1987;27(4):254-64. doi: 10.1097/00004397-198702740-00005 